\title{
Factors Affecting Soybean Root Colonization by Calonectria ilicicola and Development of Red Crown Rot Following Delayed Planting
}

\author{
P. U. Kuruppu, Parks Library, Iowa State University, Ames 50011; R. W. Schneider, Department of Plant Pathology \\ and Crop Physiology, Louisiana State University Agricultural Center, Baton Rouge 70803; and J. S. Russin, De- \\ partment of Plant and Soil Science, Southern Illinois University, Carbondale 62901-4415
}

\begin{abstract}
Kuruppu, P. U., Schneider, R. W., and Russin, J. S. 2004. Factors affecting soybean root colonization by Calonectria ilicicola and development of red crown rot following delayed planting. Plant Dis. 88:613-619.

Field studies were conducted in 1994, 1995, and 1996 to determine the effects of planting date, cultivar susceptibility, and soil pathogen population on soybean root colonization by Calonectria ilicicola and subsequent development of red crown rot. Early season colonization of roots was important for red crown rot symptom development. Symptom development in the more susceptible cultivar, Sharkey, was reduced following delayed planting and remained low in the less susceptible cultivar, Cajun, regardless of planting date. Taproot colonization was positively correlated with inoculum density during all three growing seasons but was strongest in 1994. Also, lateral root colonization correlated positively with inoculum density in 1994, the only year in which foliar symptoms were detected. A substantial decrease in inoculum density in 1995, along with reduced soybean root colonization, were attributed to high soil temperatures and probably low rainfall recorded during that summer. The effect of soybean plant age on root colonization was examined by exposing plants to the pathogen at different ages. Soybean plants were most susceptible to $C$. ilicicola during the first week after seedling emergence. By the second week, susceptibility was reduced by nearly half, and it remained near that level for the next several weeks.
\end{abstract}

Additional keywords: cultural control, host susceptibility

Red crown rot of soybean (Glycine max (L.) Merr.) is caused by the soilborne fungus Calonectria ilicicola Boedijn \& Reitsma (synonym C. crotalariae) (2,3,9, 15,25). Cylindrocladium parasiticum (synonym Cylindrocladium crotalariae) is the imperfect stage of this fungus $(2,9,15)$. This fungus also causes Cylindrocladium black rot (CBR) of peanut (2). Foliar symptoms of red crown rot usually appear during early pod development $\left(\mathrm{R}_{3}\right)$ to full pod development $\left(\mathrm{R}_{4}\right)$ and include leaf chlorosis and interveinal necrosis followed by defoliation $(3,10)$. The fungus colonizes soybean roots, and reddish-brown perithecia appear in the crown region of the plant coincidentally with foliar symptoms. Perithecia are diagnostic signs of the disease. Microsclerotia produced in host root tissue serve as survival and dispersal structures which can persist for several years in soil or host debris (2). Yield losses have been estimated to be as high as 50\% (3).

Earlier work showed that delays in planting reduce the incidence of red crown

Corresponding author: R. W. Schneider
E-mail: rschnei@LSU.edu

Accepted for publication 18 December 2003.

Publication no. D-2004-0405-01R

(C) 2004 The American Phytopathological Society rot of soybean $(4,26)$; however, the cause of this phenomenon is not clear. Bell (1), as well as Phipps and Beute (22), reported that soil temperature was a critical environmental factor affecting development of black root rot of peanut. Black et al. (7) observed that black root rot severity was greater when peanuts were planted on 2 May (minimum soil temperature $<18^{\circ} \mathrm{C}$ ) than on 17 or 30 May (minimum soil temperature $\geq 18^{\circ} \mathrm{C}$ ). These reports on peanut suggest a possible role for soil temperature in reducing disease incidence following delayed planting.

Development of both black rot of peanut $(7,14)$ and red crown rot of soybean $(4)$ are affected by host susceptibility. High levels of resistance to red crown rot have not been demonstrated in soybean, but some cultivars are known to be less susceptible (12). Also, according to Kim et al. (13), soybean plants less than 20 days old were less susceptible to $C$. ilicicola than plants 20 to 30 days old. Severity of black rot in peanut also depends upon inoculum density (ID) of C. ilicicola expressed as microsclerotia per gram of soil (21). Taylor et al. (30) described a linear relationship between peanut root colonization and field ID of C. ilicicola. Consequently, reduction of initial ID through crop rotation and chemical methods is recommended for black rot management in peanut $(20,28)$. The relationship between soybean root colonization and ID of $C$. ilicicola is not known.

The primary objectives of this study were to examine the effects of delayed planting and host age on soybean root colonization by $C$. ilicicola and development of red crown rot on cultivars that differ in susceptibility. In addition, we examined the relationship between soybean root colonization and ID of $C$. ilicicola in field soil as well as changes in ID during three consecutive years in a soybean field.

\section{MATERIALS AND METHODS}

Effects of planting date, cultivar susceptibility, and inoculum density. Field experiments were conducted in 1994, 1995, and 1996 in a field with a history of red crown rot at the Ben Hur Research Farm of the Louisiana State University Agricultural Center in Baton Rouge. The soil type was Mhoon silty clay loam (15). The experimental design was a split plot with three planting dates 3 weeks apart as main plots and two cultivars as subplots. The first planting was in the last week of May, which falls in the optimal planting time for determinant soybean cultivars in the southern United States (8) and is referred to as the optimal planting date herein. Optimal planting dates were 25 May 1994, 24 May 1995, and 30 May 1996. Delayed planting dates were 3 weeks later in mid-June and 6 weeks later in early July. Cultivars were Sharkey and Cajun, both of which exhibit a determinant growth habit and are in maturity group VI. Sharkey was rated as the most susceptible and Cajun was one of the least susceptible among 18 cultivars screened previously for red crown rot resistance in the same field (12). Treatments were replicated six times. Each plot had four rows that were $7.6 \mathrm{~m}$ long and planted on $0.76-\mathrm{m}$ centers. These plots were not disrupted by tillage after each growing season to avoid pathogen movement among plots, and both cultivars were planted in the same plots in all three growing seasons. During all 3 years, soil temperature at a depth of 10 $\mathrm{cm}$ was recorded every hour using thermistors attached to Campbell $21 \mathrm{X} \mathrm{mi-}$ crologgers (Campbell Scientific, Inc., Logan, UT). Rainfall data during all 3 years were obtained from a weather station adjacent to the plot and operated by the Louisiana Office of State Climatol- 
ogy, Louisiana State University, Baton Rouge.

Soil samples were collected every 3 weeks from planting until harvest and every 2 to 3 months during the fallow period. Approximately $500 \mathrm{~g}$ of soil were collected with soil probes to a depth of 10 to $15 \mathrm{~cm}$ from arbitrarily selected sites from the inner two rows in each plot. Samples were stored in plastic bags at room temperature ( 25 to $27^{\circ} \mathrm{C}$ ) and assayed for populations of $C$. ilicicola within 2 to 3 weeks after collection. Storage at this temperature had no effect on microsclerotial germination (24). Each sample was mixed well by hand, and a 100 -g subsample was dried at $105^{\circ} \mathrm{C}$ for $48 \mathrm{~h}$ to determine soil moisture content. The method of Phipps et al. (23), with modifications, was used to enumerate microsclerotia in the soil. A 250 -g portion of the soil sample was blended with $100 \mathrm{ml}$ of water, and the suspension was passed through nested sieves of $150 \mu \mathrm{m}$ over $45 \mu \mathrm{m}$ pore size. Material on the $45-\mu \mathrm{m}$ sieve was backwashed with water, and the soil suspension was mixed with $\mathrm{NaOCl}(0.25 \%)$ for $30 \mathrm{~s}$. This suspension then was poured over a $45-\mu \mathrm{m}$ sieve and washed with $200 \mathrm{ml}$ of water. One milliliter of this soil suspension was mixed with $100 \mathrm{ml}$ of modified Phipps semiselective medium that had been autoclaved and cooled to $50^{\circ} \mathrm{C}$. Basic constituents of this medium were: glucose, $15 \mathrm{~g}$; yeast extract, $0.5 \mathrm{~g} ; \mathrm{KNO}_{3}, 0.5 \mathrm{~g}$; $\mathrm{MgSO}_{4} \cdot 7 \mathrm{H}_{2} \mathrm{O}, 0.5 \mathrm{~g}$; agar, $20 \mathrm{~g}$; and distilled water, 1 liter. After autoclaving, each $100-\mathrm{ml}$ aliquot of the medium was amended with Tergitol, $0.05 \mathrm{ml}$; thiabendazole $(10 \mathrm{mg}$ suspended in $50 \mathrm{ml}$ of water), $0.5 \mathrm{ml}$; chloramphenicol (1 $\mathrm{g}$ dissolved in $50 \mathrm{ml}$ of $95 \%$ ethanol), $0.5 \mathrm{ml}$; and chlortetracycline $(0.4 \mathrm{~g}$ dissolved in 50 $\mathrm{ml}$ of $50 \%$ ethanol), $0.5 \mathrm{ml}$. The medium, mixed with the soil suspension, was poured into five petri plates $(9 \mathrm{~cm}$ diameter). These plates were incubated for 7 to 10 days at room temperature $\left(25\right.$ to $\left.27^{\circ} \mathrm{C}\right)$, after which the number of $C$. ilicicola colonies in all five plates was determined.

Colonization of soybean roots by $C$. ilicicola was monitored approximately every 3 weeks throughout the growing season beginning 3 weeks after planting. At each sampling date, four plants were uprooted randomly from the two outer rows of each plot. Root systems were washed thoroughly and cut into segments 1 $\mathrm{cm}$ in length. When plants were small, the entire root system was assayed. When plants were larger, 50 and 20 segments were selected at random from the lateral roots and taproots, respectively. In 1994, lateral and taproots were assayed separately only for the first and last sampling. In 1995 and 1996, taproots and lateral roots were always assayed separately. Root segments were surface-sterilized in $0.25 \%$ $\mathrm{NaOCl}$ for $30 \mathrm{~s}$, rinsed three times in sterile water, and blotted on sterile filter paper.
Root segments then were plated on modified Phipps medium and incubated at room temperature under continuous fluorescent light for 10 to 14 days. Root colonization was expressed as percentage of root segments from which colonies of C. ilicicola grew.

Numbers of plants with or without symptoms and signs of red crown rot in the inner two rows of each plot were recorded approximately every 2 weeks. Areas under disease progress curves (AUDPC) for disease incidence on each cultivar and planting date were calculated as described by Shaner and Finney (27).

Data were analyzed using the General Linear Models procedure of SAS (SAS Institute, Cary, NC) to determine the main and interactive effects of planting date, cultivar, and time of sampling on disease incidence, root colonization, and ID. Treatments were compared using least squares means. Correlation analysis was used to examine relationships of root colonization with planting date, cultivar, and ID.

Effects of host age on susceptibility. Cultures of C. ilicicola isolate SG915 (12) were grown on potato dextrose agar (PDA) at $25^{\circ} \mathrm{C}$ for 6 weeks. Mycelia and microsclerotia in agar were blended in distilled water for $1 \mathrm{~min}$ at low speed in a commercial blender, and the slurry was poured through nested sieves of 425 over $150 \mu \mathrm{m}$ pore size. Microsclerotia collected on the $150-\mu \mathrm{m}$ pore size sieve were washed under a stream of water to dislodge and remove hyphal fragments. Microsclerotia were then suspended in distilled water and enumerated. Plastic pots $(20 \mathrm{~cm}$ diameter $)$ were filled with $1 \mathrm{~kg}$ of field soil collected from Ben Hur Research Farm. This soil contained no detectable $C$. ilicicola when assayed as described above. Eight glass test tubes $(1 \times 8 \mathrm{~cm})$ were inserted in each pot to facilitate soil infestation without damaging plant roots. Glass tubes were placed in a pattern of two concentric circles (four in each circle) approximately 10 and $15 \mathrm{~cm}$ in diameter. Positions of tubes in the outer circle alternated with those in the inner circle. Tubes in the outer and inner circles were placed 8 and $4 \mathrm{~cm}$ deep, respectively. A single pregerminated seed of the susceptible cultivar Sharkey was planted at the center of each pot. Six plants were established in this manner each week for 9 weeks. During the ninth week, glass tubes in each pot were removed from the soil, and $100 \mathrm{ml}$ of a microsclerotial suspension sufficient to yield a final infestation level of 50 microsclerotia per gram of soil was pipetted into the soil depressions made by the tubes. Each depression received approximately $12.5 \mathrm{ml}$ of microsclerotial suspension. Depressions were filled with dry soil while the microsclerotial suspension was being added.

Plants were allowed to grow in the greenhouse $\left(25 \pm 5^{\circ} \mathrm{C}\right)$ and were harvested
2 weeks after introducing inoculum into soil. Soybean roots were freed from soil by gentle washing under a stream of water. Tap and lateral roots were separated and then cut into segments $1 \mathrm{~cm}$ in length. From these, 20 taproot and 50 lateral root segments were selected at random. The root assays for $C$. ilicicola were conducted as described above. This experiment was conducted twice. Data were analyzed using the General Linear Models procedure of SAS to determine the effects of host age at the time of inoculation on soybean root colonization by $C$. ilicicola. Treatment means were compared using least squares means.

\section{RESULTS}

In 1994, the average weekly maximum soil temperature was 24 to $25^{\circ} \mathrm{C}$ after 23 April (nearly 4 weeks prior to the optimal planting time) (Fig. 1). Temperatures increased after that time and were 35 to $39^{\circ} \mathrm{C}$ after 13 August until 10 September (nearly 4 weeks), and they remained between 30 to $35^{\circ} \mathrm{C}$ for four additional weeks and declined below $30^{\circ} \mathrm{C}$ after 15 October. The level of germinable microsclerotia of $C$. ilicicola in soil was low, about $2 \mathrm{CFU} \mathrm{g}^{-1}$ soil, at optimal planting time (25 May) in 1994. It increased steadily over the next several weeks and reached a maximum of $16 \mathrm{CFU} \mathrm{\textrm {g } ^ { - 1 }}$ soil during September then decreased during the winter. Inoculum densities were similar in plots with cultivars Sharkey and Cajun until the beginning of September, which was 14 weeks after the first planting date (Fig. 2). At that time, the ID in soil planted to the susceptible cultivar Sharkey increased to a level nearly twice that in soil planted to the less susceptible cultivar Cajun (23 versus $13 \mathrm{CFU} \mathrm{g}^{-1}$ soil), and this difference remained constant through the end of the year. Total rainfall during soybean planting times (between 15 May and 16 July) and during the period between soybean planting and early reproductive stages (between 15 May and 2 September) was 36.8 and $54.6 \mathrm{~cm}$, respectively, in 1994.

Soil temperatures in 1995 averaged about $5^{\circ} \mathrm{C}$ higher than in 1994 (Fig. 1). Soil temperature reached $24^{\circ} \mathrm{C}$ by 9 April, which was 2 weeks earlier than in 1994, and was higher than $30^{\circ} \mathrm{C}$ by 21 May (only a few days prior to the optimal planting time). Temperatures were equal to or higher than $35^{\circ} \mathrm{C}$ in the 9-week period from 16 July to 17 September and averaged $41^{\circ} \mathrm{C}$ and $42^{\circ} \mathrm{C}$ during 2 weeks (Fig. 1). In 1995 , total rainfall was $15 \mathrm{~cm}$ during soybean planting times (between 15 May and 16 July) and $30.2 \mathrm{~cm}$ during the period between soybean planting and $R_{1}$ to $R_{3}$ reproductive stages (between 15 May and 2 September). Inoculum density of C. ilicicola in soil initially was higher in 1995 than in 1994, averaging $17 \mathrm{CFU} \mathrm{g}^{-1}$ across cultivars at the first planting date (24 May). However, it dropped to less than 


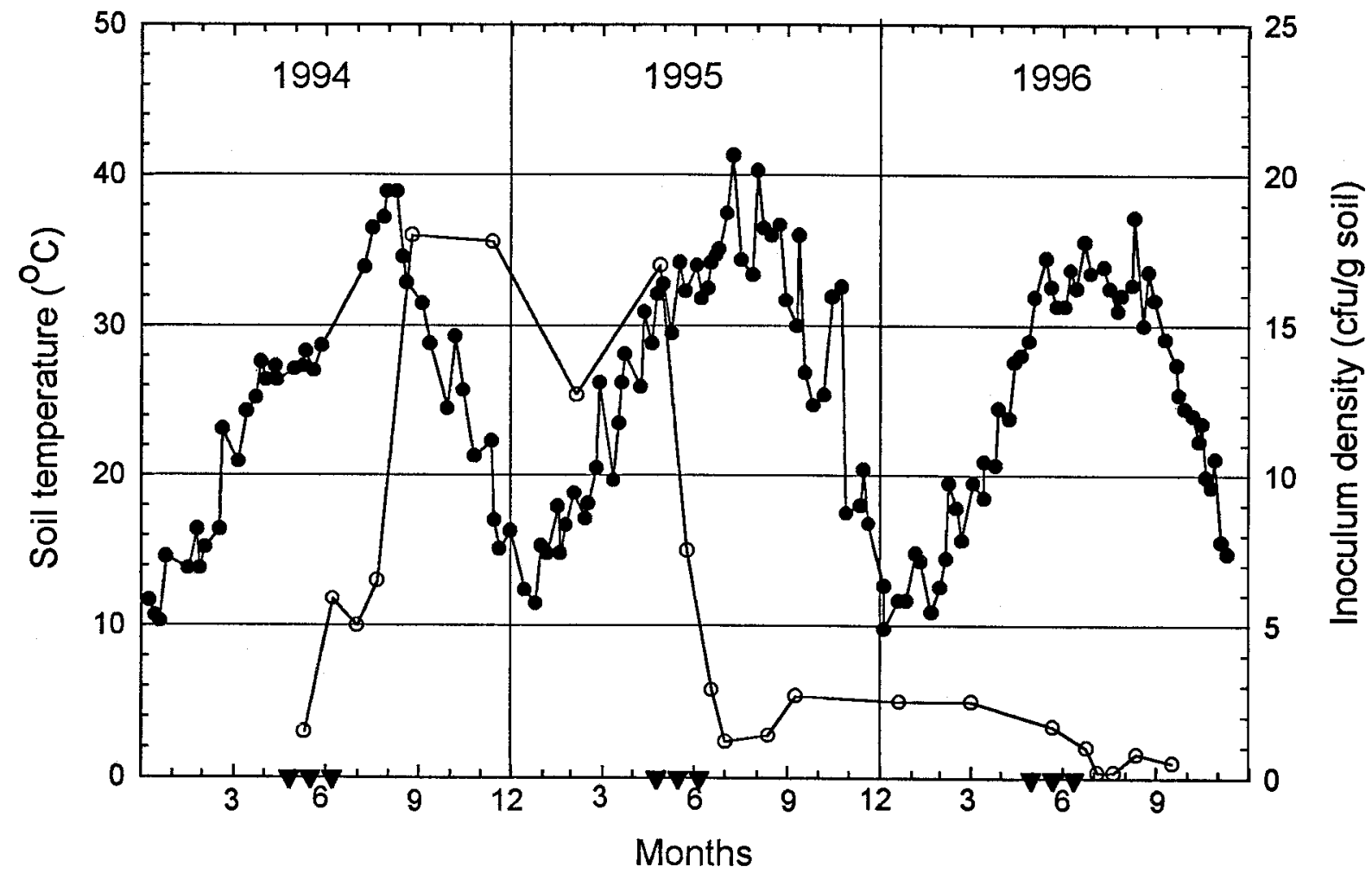

\section{$\longrightarrow$ Maximum soil temperature \\ - Inoculum density}

Fig. 1. Inoculum density of Calonectria ilicicola and weekly average maximum soil temperatures $(\mathrm{depth}=10 \mathrm{~cm})$ in 1994 , 1995, and 1996. Arrows in each year indicate three planting dates.

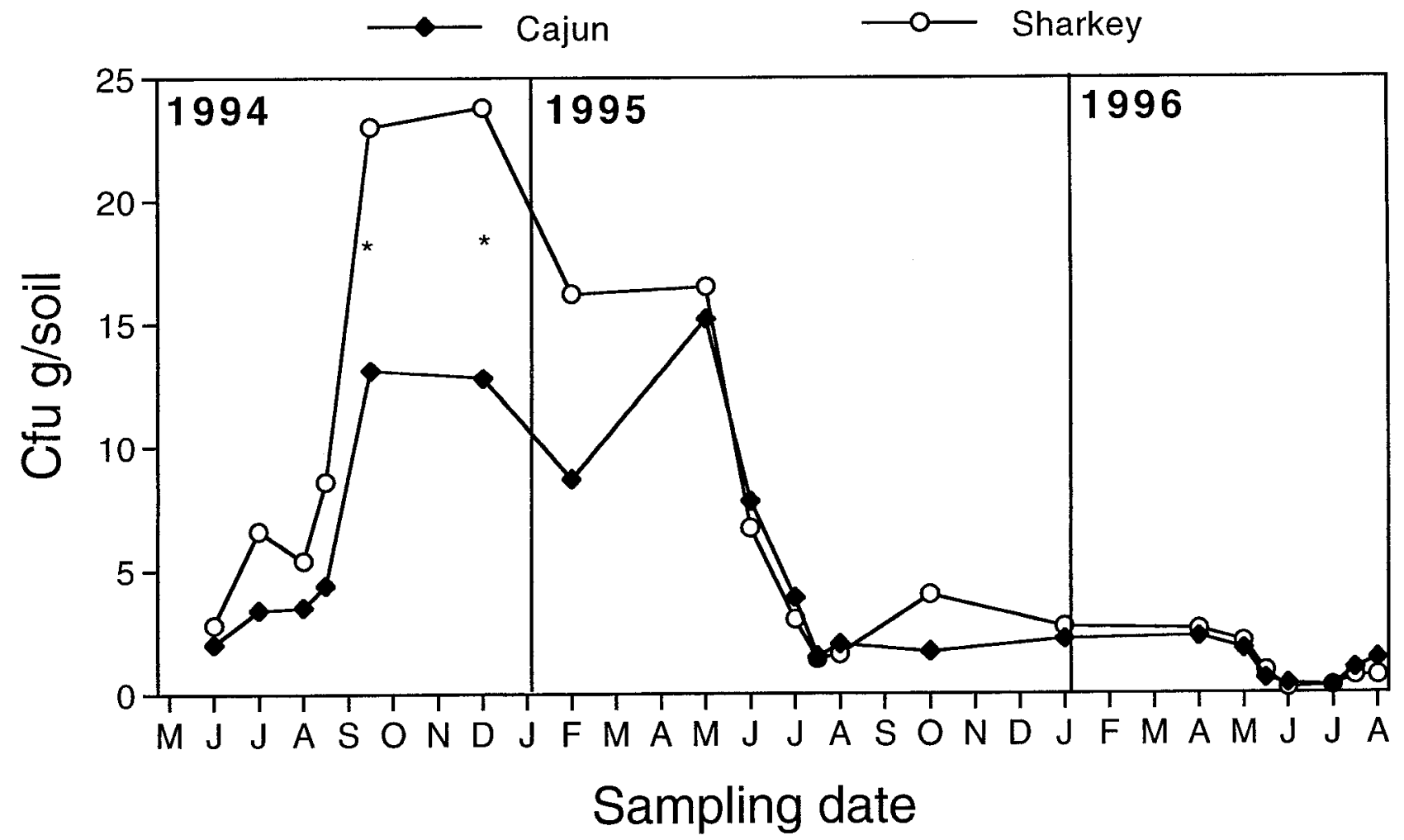

Fig. 2. Inoculum density of Calonectria ilicicola in 1994, 1995, and 1996. Differences between cultivars were significant only on dates marked with an asterisk according to least squares means $(P \leq 0.05)$. 
Table 1. Correlations between inoculum density ${ }^{\mathrm{a}}$ of Calonectria ilicicola in soil and colonization ${ }^{\mathrm{b}}$ of soybean lateral, tap, and total roots by C. ilicicola in 1994, 1995, and 1996

\begin{tabular}{lcccccccc}
\hline & \multicolumn{2}{c}{ Lateral } & & \multicolumn{2}{c}{ Tap } & & \multicolumn{2}{c}{ Total } \\
\cline { 2 - 3 } \cline { 7 - 8 } Year & $\boldsymbol{r}^{\mathbf{c}}$ & $\boldsymbol{P}^{\mathbf{d}}$ & & $\boldsymbol{r}$ & $\boldsymbol{P}$ & & $\boldsymbol{r}$ & $\boldsymbol{P}$ \\
\hline 1994 & 0.7229 & 0.0001 & & 0.3877 & 0.0065 & & 0.4861 & 0.0001 \\
1995 & 0.2621 & 0.0015 & & 0.2310 & 0.0053 & & 0.2812 & 0.0006 \\
1996 & 0.1324 & 0.1719 & & 0.2988 & 0.0017 & & 0.2610 & 0.0064 \\
\hline
\end{tabular}

a Number of colony forming units of $C$. ilicicola per gram of soil.

b Percentage of $1-\mathrm{cm}$ root segments from which colonies of C. ilicicola grew.

c Pearson correlation coefficient.

${ }^{\mathrm{d}} \operatorname{Prob}>|\mathrm{R}|$.

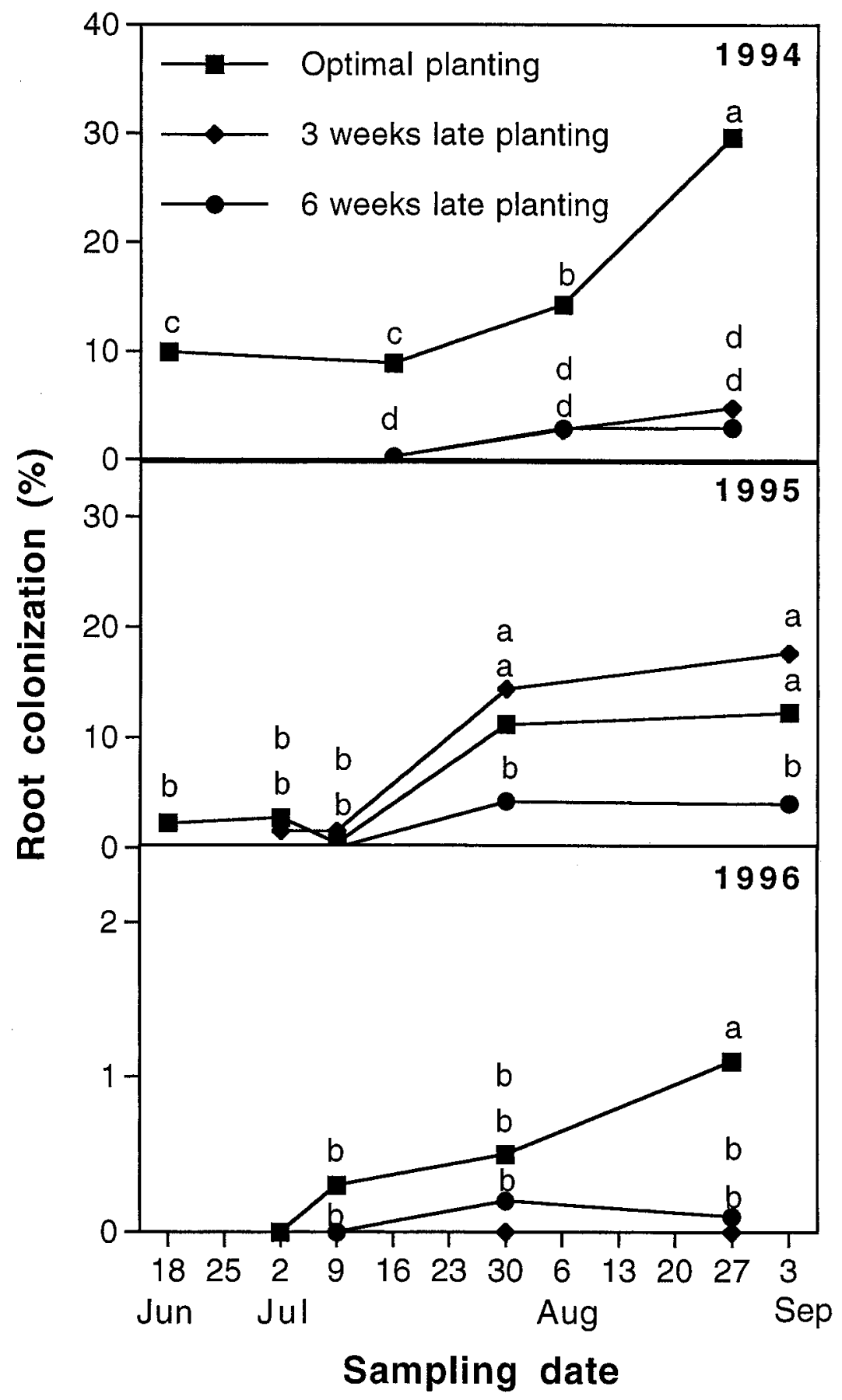

Fig. 3. Soybean root colonization by Calonectria ilicicola following three planting dates in 1994, 1995, and 1996. Optimal planting was on 25, 24, and 30 May in 1994, 1995, and 1996, respectively. Data are expressed as means across soybean cultivars Sharkey and Cajun. Means marked with the same letter did not differ significantly in each year according to least squares means $(P \leq$ $0.05)$.
$2 \mathrm{CFU} \mathrm{g}^{-1}$ soil by the third planting date (13 June) and remained very low (less than $3 \mathrm{CFU} \mathrm{g}{ }^{-1}$ soil) throughout the remainder of the season. This drop in ID corresponded with the period during which maximum soil temperature was $33^{\circ} \mathrm{C}$ or above, and there were no significant differences in ID's between plots of the two cultivars in 1995 (Fig. 2).

Populations of C. ilicicola in soil remained very low during 1996, despite the fact that maximum soil temperatures were lower than in 1995 (Fig. 1). Total rainfall was $18 \mathrm{~cm}$ during soybean planting times (between 15 May and 16 July) and 42.9 $\mathrm{cm}$ between soybean planting and early reproductive stages (between 15 May and 3 September).

In 1994, ID of C. ilicicola correlated positively with tap, lateral, and total root colonization by $C$. ilicicola, but the correlation was far stronger for lateral than for taproots (Table 1). This relationship also was detected in 1995, but values for $r$ were lower. In 1996, there were positive correlations between ID and both tap and total root colonization but not with lateral root colonization.

Colonization of soybean roots was detected as early as 1 week after planting in 1994. Root colonization at that time generally was not accompanied by visible discoloration or necrosis. In 1994, total root colonization across both cultivars at the optimal planting date averaged nearly $10 \%$ by 18 June ( 3 weeks after planting) and remained at that level through 16 July. It increased steadily thereafter and reached nearly $30 \%$ by 27 August. Planting delays of 3 or 6 weeks resulted in much lower levels of root colonization (less than 4\%) by $C$. ilicicola. Total root colonization levels did not differ between these late planting dates and did not increase as the season progressed. In 1995, early season root colonization across both cultivars was considerably lower (2 versus $10 \%$ ) than in 1994 (Fig. 3). For the first two planting dates, total root colonization reached about $12 \%$ by 5 August and exhibited little change through the end of the season. By this time, root colonization in the last planting was lower than that in earlier plantings and remained low throughout the remainder of the season. Root colonization in 1996 was not detected until 9 July in the optimal planting and remained very low (less than 2\%) throughout the remainder of the season (Fig. 3). Root colonization in the late plantings was significantly lower than that in the optimal planting only on the last sampling date (Fig. 3). Following the optimal planting date in 1994, total root colonization of the susceptible cultivar Sharkey was greater than that for the less susceptible cultivar Cajun during the first 7 weeks after planting (until 12 July). No differences in total root colonization were detected between these cultivars at later sampling dates. When colonization of tap 
and lateral roots in 1994 was examined separately, only lateral root colonization differed at 15 June. This difference was not detected at 23 August. No differences in tap, lateral, and total root colonization were detected between cultivars when planting was delayed 3 and 6 weeks. In 1995 , total root colonization was higher in Sharkey only after 25 July in the planting delayed by 3 weeks. In 1996, root colonization was higher in Sharkey in the optimal planting only at 9 September. However, early root colonization did not differ between these cultivars in 1995 and 1996.

Foliar symptoms (leaf chlorosis and interveinal necrosis) and/or signs (perithecia) were observed only in 1994 and appeared at the beginning of reproductive growth. Disease first was detected in Sharkey at the early reproductive stages, about 10 weeks after planting, regardless of planting date. Disease incidence in Sharkey was high and averaged about $20 \%$ following optimal planting, whereas disease in the less susceptible Cajun was lower at all sampling dates (Fig. 4). When planting was delayed 3 weeks, disease incidence in Sharkey was lower than that following optimal planting and was greater than that in Cajun only at the last three sampling dates. There was no significant difference in disease incidence between cultivars when planting was delayed 6 weeks. Incidence of red crown rot was consistently low $(\leq 7 \%)$ in Cajun regardless of planting date. Values for area under disease progress curves (AUDPC) for Sharkey showed a stepwise decrease with delay in planting, whereas AUDPC for Cajun remained low and did not decrease in response to planting date.

The effect of host age at the time of inoculation with the pathogen was significant for both tap and lateral root colonization. Maximum taproot $(50 \%)$ as well as lateral root $(35 \%)$ colonization was detected 2 weeks after a pregerminated seed of Sharkey soybean was planted in soil with the pathogen (Fig. 5). Both tap and lateral root colonization levels were reduced approximately 50\% when the pathogen was placed in soil 1 week after planting. Root colonization remained at about this level throughout the soil infestation time series up to 8 weeks after seedling emergence.

\section{DISCUSSION}

Two previous studies showed that red crown rot incidence in soybean was reduced following delayed planting $(4,26)$. Results from this study support these findings and show that a planting delay of 3 or 6 weeks reduced AUDPC for red crown rot about 50 and $75 \%$, respectively. Our results also address the mechanism responsible for this reduction. Analysis across both soybean cultivars revealed that initial and final root colonization by C. ilicicola were reduced when planting was delayed either
3 or 6 weeks. This effect was observed in two differentially susceptible cultivars. Separate analyses for each cultivar provided additional insight into this reduction. As expected, red crown rot incidence on the susceptible cultivar Sharkey was much greater than that on the less susceptible cultivar Cajun, both of which were planted at the optimal planting date in 1994. However, root colonization levels differed between these two cultivars only within about 7 weeks after optimal planting, not later in the season when symptoms were evident. These findings show that development of foliar symptoms during reproductive growth depends on colonization of roots by C. ilicicola during the first few weeks following optimal planting time. The very low level of early root colonization and absence of red crown rot symptoms, even in the susceptible cultivar Sharkey in 1995 and 1996, further support this conclusion. Tap and lateral root colonization were considered separately in

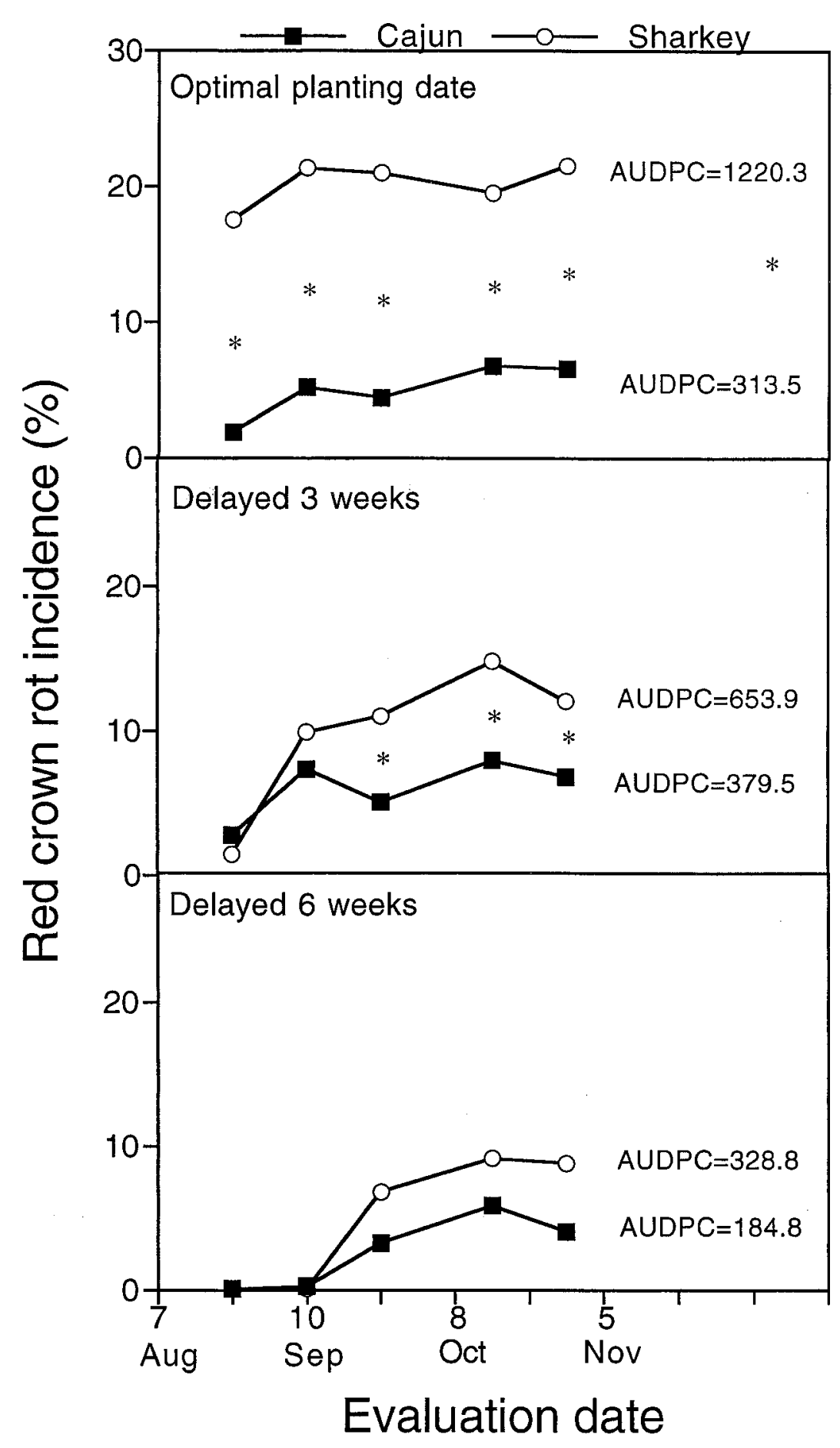

Fig. 4. Incidence of red crown rot in two soybean cultivars, Sharkey and Cajun, planted in 1994 and area under disease progress curves (AUDPC). Asterisks indicate significant $(P \leq 0.05)$ differences between cultivars at each evaluation according to least squares means and AUDPC for a planting date. 
both cultivars during 1994, the year when symptoms of red crown rot were evident. Only lateral root colonization differed between cultivars during the short period following the optimal planting time. These results indicate the importance of early colonization of the entire root system for subsequent development of red crown rot. Taylor et al. (30) isolated the pathogen from soybean roots with little or no root rot. Our observations indicate that soybean roots were colonized by $C$. ilicicola during very early vegetative stages, and this colonization generally was not accompanied by visible root discoloration.
Differential host responses to pathogens based on host age are well known. Soybean plants in early growth stages were more susceptible to stem canker, caused by Diaporthe phaseolorum var. caulivora $(17,29)$, but less susceptible to brown stem rot, caused by Phialophora gregata (19). Using the same pathosystem as in the present study, Kim et al. (13) reported that younger soybean plants were less susceptible to infection by $C$. ilicicola and suggested that reduced incidence of red crown rot following delayed planting may result from lower susceptibility of younger plants. Their results are in direct contrast

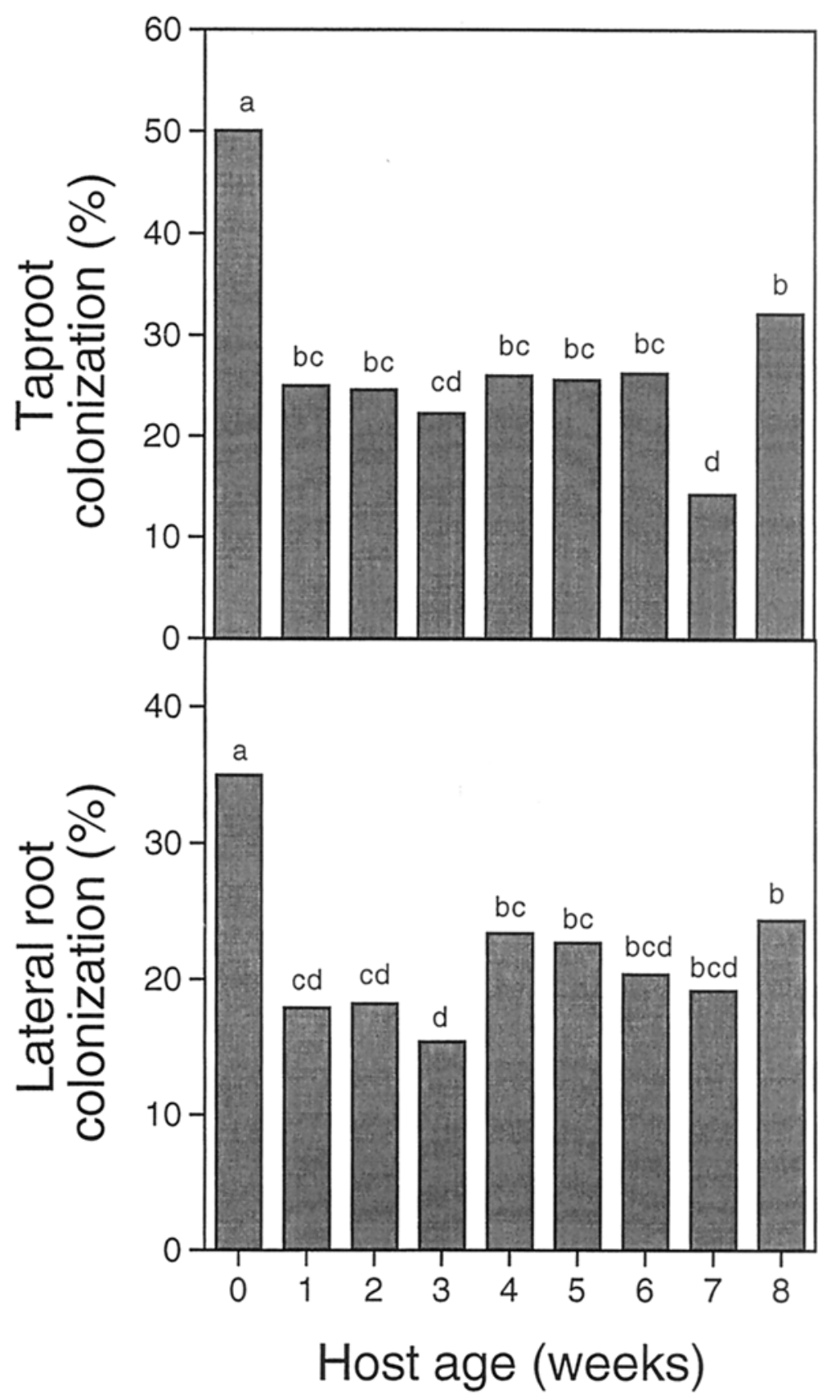

Fig. 5. Relationship between age of soybean plants and tap and lateral root colonization by Calonectria ilicicola at time of inoculation. Microsclerotia of $C$. ilicicola were introduced into soil when soybean plants were $0,1,2,3,4,5,6,7$, or 8 weeks old, and root colonization was determined 2 weeks later. Bars with the same letter in each panel did not differ significantly $(P \leq 0.05)$ according to least squares mean. to those of the present study. An explanation for this contrast was evident when inoculation methods were compared. Kim et al. (13) inoculated soybean plants of different ages by placing mycelium of $C$. ilicicola in agar disks at stem bases and measuring lesion length and number of perithecia produced on stems. In contrast, root colonization in this study was assessed in soil infested with microsclerotia, and we suggest that this is more representative of field conditions. Contrary to the findings of Kim et al. (13), our results indicate that soybean roots were more susceptible to root colonization during the first week after emergence and remained susceptible for at least 8 weeks. Consequently, we conclude that reduced incidence of red crown rot following delayed planting does not result from lower susceptibility to root colonization in younger plants.

The difference in root colonization between Cajun and Sharkey was more apparent in the lateral roots, as compared to taproots, suggesting that reduced disease incidence in Cajun is related to its ability to limit early lateral root colonization by C. ilicicola. Harris and Beute (11) reported that less susceptible peanut cultivars reduced pathogen entry into the vascular system through periderm production in the taproot. Histological changes in response to this pathogen in soybean roots have not been examined.

Populations of C. ilicicola in soil planted to soybean cultivars differing in susceptibility were not consistent during the three consecutive growing seasons. A higher ID of C. ilicicola in plots planted to the susceptible Sharkey was detected toward the end of 1994, perhaps caused by the deterioration of the more heavily colonized Sharkey lateral roots. Black et al. (7) reported that the mean population density was lower following monoculture for 4 years with a resistant peanut cultivar than with a susceptible cultivar. However, Black and Beute (6) did not observe an increase in soil ID of C. ilicicola after two cycles of 2 to 3 months of monoculture of peanut or soybean in greenhouse experiments. In our study, continuous cultivation of a susceptible host for three consecutive years did not result in increased $C$. ilicicola populations in field plots. This suggests that factors other than the presence of a susceptible cultivar influence inoculum level of $C$. ilicicola in soybean fields. The dramatic decrease in ID associated with increased soil temperatures during the summer of 1995 suggests that soil temperature exerts a major effect on the survival of this pathogen.

Understanding the relationship between ID of C. ilicicola and root colonization is important in the study of disease development and management of red crown rot disease in soybean. Reduced initial root colonization in 1995, in spite of high 
pathogen populations during planting time, was unexpected after detecting a strong positive correlation between ID and root colonization in the previous year. Reduced early season root colonization in 1995, in spite of high IDs, may be attributable to high soil temperatures experienced during the early portion of the growing season. Black and Beute (5) and Black et al. (7) suggested that factors other than the numbers of microsclerotia in soil affect the severity of black root rot of peanut. It also was reported that black root rot is largely affected by soil temperature and soil moisture $(18,22)$. The apparent irreversible decline in pathogen ID in 1995 was associated with abnormally high soil temperatures and lower rainfall compared with 1994. We could not separate these two environmental variables in this investigation. Therefore, a comparison study was completed on the effects of soil temperature under constant soil moisture conditions on survival of and soybean root colonization by $C$. ilicicola (16).

Our results indicate that environmental conditions conducive to soybean root colonization by $C$. ilicicola, which are critical for the development of red crown rot in soybean, occur for a short period following the optimal planting time in the beginning of summer. Therefore, it is advisable to avoid this period when planting susceptible soybean cultivars in fields with a history of red crown rot. However, delays in planting may reduce yield apart from that caused by red crown rot (8). Growers must choose planting dates for susceptible cultivars to offset yield losses caused by delayed plantings versus yield losses attributable to red crown rot.

\section{LITERATURE CITED}

1. Bell, D. K. 1967. Effects of soil temperature and plant age on the severity of Cylindrocladium rot of peanut. Plant Dis. Rep. 51:986988.

2. Bell, D. K., and Sobers, E. K. 1966. A peg, pod and root necrosis of peanuts caused by a species of Calonectria. Phytopathology 56:1361-1364.

3. Berggren, G. T., Jr., and Snow, J. P. 1989. Red crown rot. Pages 44-45 in: Compendium of Soybean Diseases. 3rd ed. J. B. Sinclair and P.
A. Backman, eds. American Phytopathological Society, St. Paul, MN.

4. Berner, D. K., Berggren, G. T., Snow, J. P., and White, E. P. 1988. Distribution and management of red crown rot of soybean in Louisiana. Appl. Agric. Res. 3:160-166.

5. Black, M. C., and Beute, M. K. 1984. Relationships among inoculum density, microsclerotium size, and inoculum efficiency of Cylindrocladium crotalariae causing root rot on peanuts. Phytopathology 74:1128-1132.

6. Black, M. C., and Beute, M. K. 1985. Soil components that affect severity of Cylindrocladium black rot on peanuts. Plant Dis. 69:3639.

7. Black, M. C., Pataky, J. K., Beute, M. K., and Wynne, J. C. 1984. Management tactics that complement host resistance for control of Cylindrocladium black rot of peanut. Peanut Sci. 11:70-73.

8. Boquet, D. J. 1994. Soybean production practices. Pages 8-10 in: Handbook of Soybean Insect Pests. L. G. Highley and D. J. Boethel, eds. Entomological Society of America, Lanham, MD.

9. Crouse, P. W., Wingfield, M. J., and Alfenas, A. 1993. Cylindrocladium paraciticum sp. nov., a new name for $C$. crotalariae. Mycol. Res. 97:889-890.

10. Fehr, W. R., Caviness, C. E., Burmood, D. T., and Pennington, J. S. 1971. Stage of development descriptions for soybeans, Glycine max (L.) Merrill. Crop Sci. 11:929-931.

11. Harris, N. E., and Beute, M. K. 1982. Histological responses of peanut germplasm resistant and susceptible to Cylindrocladium crotalariae in relationship to inoculum density. Phytopathology 72:1250-1255.

12. Kim, K. D. 1994. Susceptibility in soybean to red crown rot and characteristics of virulence in Calonectria crotalariae. Ph.D. diss. Louisiana State University, Baton Rouge.

13. Kim, K. D., Russin, J. S., and Snow, J. P. 1998. Effect of plant age on infection of soybean by Calonectria ilicicola. Kor. J. Plant Pathol. 14:247-252.

14. Krigsvold, D. T., Griffin, G. J., and Hale, M. G. 1982. Microsclerotia germination of Cylindrocladium crotalariae in the rhizospheres of susceptible and resistant peanut plants. Phytopathology 72:859-883.

15. Kuruppu, P. U. 1998. Factors affecting root colonization by Calonectria ilicicola and development of red crown rot disease on soybean. Ph.D. diss. Louisiana State University, Baton Rouge.

16. Kuruppu, P. U., Schneider, R. W., and Russin, J. S. 2004. Effects of soil temperature on microsclerotia of Calonectria ilicicola and soybean root colonization by this fungus. Plant Dis. 88:620-624.

17. Padgett, G. B. 1992. The epidemiology of
soybean/Diaporthe phaseolorum var. caulivora pathosystem in Louisiana. Ph.D. diss. Louisiana State University, Baton Rouge.

18. Pataky J. K., and Beute, M. K. 1983. Effects of inoculum burial, temperature, and soil moisture on survival of Cylindrocladium crotalariae microsclerotia in North Carolina. Plant Dis. 67:1379-1382.

19. Phillips, D. V. 1972. Influence of photoperiod, plant age, and stage of development on brown stem rot of soybean. Phytopathology 62:1334 1337.

20. Phipps, P. M. 1990. Control of Cylindrocladium black rot of peanut with soil fumigants having methyl isothiocyanate as the active ingredient. Plant Dis. 74:438-441.

21. Phipps, P. M., and Beute, M. K. 1977. Sensitivity of susceptible and resistant peanut cultivars to inoculum densities of Cylindrocladium crotalariae microsclerotia in soil. Plant Dis. Rep. 61:300-303.

22. Phipps, P. M., and Beute, M. K. 1977. Influence of soil temperature and moisture on the severity of Cylindrocladium black rot in peanut. Phytopathology 67:1104-1107.

23. Phipps, P. M., Beute, M. K., and Barker, K. R. 1976. An elutriation method for quantitative isolation of Cylindrocladium crotalariae microsclerotia from peanut field soil. Phytopathology 66:1255-1259.

24. Roth, D. A., Griffin, G. J., and Graham, P. J. 1979. Low temperature induces decreased germinability of Cylindrocladium microsclerotia. Can. J. Microbiol. 25:157-162.

25. Rowe, R. C., Beute, M. K., and Wells, J. C. 1973. Cylindrocladium black rot of peanuts in North Carolina - 1972. Plant Dis. Rep. 57:387389.

26. Russin, J. S., Troxclair, N. N., Jr., Boethel, D. J., and McGawley, E. C. 1985. Effect of soybean planting date and soil nutrients on incidence of red crown rot and populations of insects associated with roots. (Abstr.) Phytopathology 75:1284.

27. Shaner, G., and Finney, R. E. 1977. The effect of nitrogen fertilization on the expression of slow-mildewing resistance in Knox wheat. Phytopathology 67:1051-1056.

28. Sidebottom, J. R., and Beute, M. K. 1989. Control of Cylindrocladium black rot of peanut with cultural practices that modify soil temperature. Plant Dis. 73:672-676.

29. Smith, E. F., and Backman, P. A. 1989. Epidemiology of soybean stem canker in the southeastern United States: Relationship between time of exposure to inoculum and disease severity. Plant Dis. 73:464-468.

30. Taylor, J. D., Griffin, G. J., and Garren, K. H. 1981. Inoculum pattern, inoculum densitydisease incidence relationship, and population fluctuations of Cylindrocladium crotalariae in peanut field soil. Phytopathology 71:1297-1302. 